\title{
More or Less Sustainable? Assessment from a Policy Perspective
}

\author{
Biljana Petrevska ${ }^{1, * \mathbb{C}}$, Aleksandra Terzić ${ }^{2}$ and Cvetko Andreeski ${ }^{3}$ \\ 1 Faculty of Tourism and Business Logistics, Goce Delčev University, 2000 Štip, Macedonia \\ 2 Geographical Institute Jovan Cvijić, SASA, 11000 Belgrade, Serbia; a.terzic@gi.sanu.ac.rs \\ 3 Faculty of Tourism and Hospitality-Ohrid, St. Kliment Ohridski University, 7000 Bitola, Macedonia; \\ cvetko.andreeski@uklo.edu.mk \\ * Correspondence: biljana.petrevska@ugd.edu.mk
}

Received: 29 March 2020; Accepted: 17 April 2020; Published: 24 April 2020

\begin{abstract}
Sustainability of tourism destinations has become the main focus in planning and managing tourism development. Despite existing legislation and an institutional framework to safeguard balanced tourism growth, many destinations fail to properly address it. So far, studies are limited in exploring sustainable tourism impacts from a policy perspective. This study follows previous ones in using the triple bottom line sustainability approach to define tourism impacts. It argues, in particular, for a nexus between understanding of policy perception and sustainability, and it applies this to tourist destinations in Serbia to determine whether they are operating sustainably. For this purpose, the data were collected using a combination of multiple methods, involving interviews with policymakers and content analysis of strategic documents. This study further suggests a model that assesses the extent of the sustainability of tourist destinations. The results illustrate the importance of understanding policy perceptions in shaping and facilitating sustainability and informing policy enablers on how to improve and reform current tourism development. The model can be adopted and applied to any tourist destination facing an inevitable need to re-shape their tourism development plans and policies, while the implications address the need to build a participative policy approach to sustainable tourism development.
\end{abstract}

Keywords: sustainability; perception; policy; tourism development; challenges; reforms

\section{Introduction}

The concept of sustainable development emerged from environmental concerns within the activities of the United Nations, reflected in the World Charter for Nature [1] and Agenda 21 [2]. It was further reoriented towards tackling socio-economic issues and reflected in a "triple pillar" context within the World Summit on Sustainable Development in Johannesburg in 2002 [3] and Rio +20 "The Future We Want" [4]. Consistent with [5-7], this concept is understood as an organizing principle for meeting human development goals while sustaining the potential of natural systems to supply the natural resources upon which society and the economy depend while aiming at achieving social, environmental, and economic progress [8,9]. Thus, sustainable development as a concept incorporates social, ecological, and economic aspects, outlining the necessity of their optimization to meet 17 sustainable development goals with 169 targets of the United Nations' Agenda 2030 [10]. However, achieving all this has been often hampered by some trade-offs and different interpretations in favor of economic growth, at the expense of social well-being and ecological viability [11].

Tourism sustainability has been long debated, and many studies from various approaches open a variety of interpretations so far. Regardless of the level of inter-dependency (destination sustainability, tourism sustainability, and sustainability of the local community), understanding the principles of 
sustainability are fundamental for sustainable tourism development [12-14]. The concept generally rests on the three theoretical pillars, representing socio-cultural, environmental, and economic tourism impacts. As such, the concept has been integrated into tourism strategies starting from a local to a global level. Taking into consideration various impacts tourism has on destinations, understanding stakeholders' perception is essential in minimizing potential negative effects and maximizing benefits, so an understanding of sustainability from different perspectives by those who live in the destination or use and manage resources means meeting the needs and requirements of all stakeholders (local communities, tourists, operators, and regulators). It is tourism that unifies all, boosting destinations to a higher quality in the short and long term, but, in order for sustainable tourism to be achievable, all tourism segments must work towards becoming sustainable, even if it looks like an incalculable goal and unattainable objective $[15,16]$. Many scholars argue about different aspects of perceptions of the sustainability of tourism, yet studies are very limited in putting the focus on policy enablers' perception [17-22]. This study follows previous findings in using the established three mainstream pillars of sustainability (socio-cultural, environmental, and economic) to define tourism impacts. It adds to the literature gap by assessing the level of tourist destinations' sustainability from a policy perspective. The policymakers represent the regulators: those who contribute to managing and controlling tourism development at the destination level (such as governmental bodies, contributors to management strategies, tourist organizations, etc.). Additionally, this study suggests a modeling framework for strategic tourism development reforms. The proposed model posts directions for the systematic organization of policymakers to infer conclusions regarding the current state of well-being of tourist destinations. It is important to assess this due to the manner of progress and to direct and monitor policies towards sustainable development.

Serbia was chosen for a case study as it seeks to develop tourism despite limitations in many aspects (lack of finances, low GDP, small investments in tourism, etc.). So far, studies have been undertaken on tourism stakeholders in Serbia [22,23], but, to our knowledge, this approach is still missing from the literature. The paper sets out the theoretical context concerning sustainability. This is followed by a brief overview of related facts and figures about the study area. The next section presents the conceptual model and methodology, followed by empirical results. Findings are discussed, followed by the concluding part of the paper.

\section{Literature Review}

Sustainable tourism has evolved from the original sustainable development concept, being able to "process the need of the present without compromising the ability of future generations to meet their own needs" [24] (p. 8). Since then, vast debates about the definition have ensued, resulting in the incorporation of sustainable development in the context of tourism needs, resulting in the definition of sustainable tourism. In general, this concept has become very popular and ever since continued to raise dilemmas about its validity and operationalization.

Over the years, as it gained in popularity, researchers extensively debated sustainable tourism issues [25]. Various aspects of sustainability were discussed, each from a different angle of scientific approach [26], yet many aspects of sustainable tourism are still overlooked in the literature, in terms of achieving a systematic perspective and an interdisciplinary approach, like the role of tourism demand, the fixed entity of tourism resources, the imperative of intra-generational equity, keeping the culture intact and usefully measured sustainability, and there has been some skepticism about tourism forms of sustainable development [27]. Some exceptions have been noted by [28,29], when arguing the case for one-site measurement used as an impact control measure and thus explaining the role of tourism demand from a sustainability perspective. An exceptionally strong focus on preservation and conservation of resources is argued for by addressing different aspects of the sustainability of tourism resources, like macro and micro sustainability approaches [30], "strong" and "weak" sustainability [31], the minimum resource condition to maintain constant stock [32], etc. Issues of inter-generational equity 
in favor of intra-generational equity as an essential prerequisite of sustainable tourism are highlighted by $[33,34]$.

Furthermore, many scholars have debated the issue of measuring sustainability by trying to identify sustainable levels of tourism development and how these can be measured. Different methodologies with a comprehensive set of indicators are proposed, and the debate is still ongoing [15,16,35-38], yet there is no consensus on a universal list of indicators capable of revealing the sustainability level of various destinations.

Furthermore, stakeholder theory has been extensively explored, allowing the understanding of perceptions of different supporters of tourism development at the destination level [39-43]. Recent debates tried explaining tourism sustainability from residents' perspectives [44-53]. The decision-making process, planning, and management of tourism sustainability have also been addressed [54-58]. Furthermore, broad-based participation of all stakeholders in the process of developing sustainability indicators is also strongly recommended [17,59-62].

\section{Study Area: Serbia}

Tourism in Serbia is recognized as one of the priority areas for development and an important task on its path towards European Union (EU) integration (Table 1).

Table 1. Summarized tourism facts for Serbia.

\begin{tabular}{cc}
\hline & $3,689,700$ tourist arrivals (49.96\% domestic and $50.04 \%$ foreign) \\
& $10,073,200$ overnight stays $(60.2 \%$ domestic and $38.8 \%$ foreign) \\
Capital cities (Belgrade and Novi Sad) $38.21 \%$ of tourist arrivals; & Spa resorts $18.16 \% ;$ \\
Mountain resorts $17.3 \% ;$ \\
Other tourist resorts $21.66 \% ;$ \\
Other resorts $4.22 \%$.
\end{tabular}

At the national level, tourism development is under the jurisdiction of the Ministry of Trade, Tourism, and Telecommunications, responsible for legal regulative measures, strategic planning and control. The main role in the marketing and promotion of tourist destinations at the national level is played by the National Tourist Organization. There are several regional tourist organizations, development agencies and tourist clusters having a direct role in tourism development and marketing. At the local level, such activities are under the control of municipal authorities and local tourist organizations. Overall, in the tourism planning and development process, a top-bottom approach is applied. This particularly concerns the issues related to infrastructure and capital investments. Table 2 presents a summarized framework of the institutional structure of tourism policymakers in Serbia. 
Table 2. The institutional structure of tourism policymakers in Serbia.

\begin{tabular}{|c|c|}
\hline Type of Institution/Organization & Profile of the Institution/Organization \\
\hline Ministry of Trade, Tourism, and Telecommunications & Sector of Tourism; Sector of Tourism Inspection \\
\hline Development Agencies & $\begin{array}{l}\text { National Agency for Regional Development (since 2009) } \\
\text { Regional Agencies: } 17 \text { (RARIS-East Serbia, RDA Rasina } \\
\text { District, RDA Pčinja district, RDA Šumadija and } \\
\text { Pomoravlje, RDA Belgrade, RDA Braničevo-Podunavlje, } \\
\text { RDA Južni Banat, RDA PANONREG, RDA Bačka, RDA } \\
\text { Srem, RDA Banat, RDA Zlatibor, RDA JUG, RDA } \\
\text { Podrinje-Podgorina-Rađevina, RDA Sandžak-SEDA, } \\
\text { Center for the development of Jablanica and Pčinja District) }\end{array}$ \\
\hline Tourist Organizations & $\begin{array}{c}\text { National Tourist Organization of Serbia } \\
\text { Regional tourist organizations: } 3 \text { (Tourist Organization of } \\
\text { Vojvodina, Tourist Organization of West Serbia, Regional } \\
\text { Tourist Organization of Sandžak) } \\
\text { Local Tourist Organizations on Municipal Level: } 132\end{array}$ \\
\hline Tourist Clusters & $\begin{array}{c}\text { Danube tourist cluster Istar } 21 \\
\text { Cluster association for the development of business, MICE } \\
\text { and event tourism } \\
\text { Cluster of health, wellness and spa tourism } \\
\text { Tourist Cluster SremCluster Sombor Salashs } \\
\text { Tourist Cluster "The Hart of Sumadija" } \\
\text { Tourist Cluster of Southeastern Serbia "Stara Planina" }\end{array}$ \\
\hline Associations & $\begin{array}{c}\text { YUTA-National Association of Tourist Agencies (327 } \\
\text { tourist agencies) of total approx. } 500 . \\
\text { HORES-business association of the hotel and restaurant } \\
\text { industry of Serbia (about } 200 \text { hotels and restaurants) } \\
\text { TGA-Tourist Guides Association of Serbia (170 licensed } \\
\text { tourist guides) }\end{array}$ \\
\hline
\end{tabular}

General sustainability frameworks are set within The National Strategy on Sustainable Development [64] and the Strategy of Tourism Development 2016-2025 [65], while different issues, measures, and goals are being emphasized in various strategic documents. They provide the overall line with the general sustainability concept, directed towards the proper balance between the three core pillars. Commonly, the focus is placed on those issues concerning the proper use of natural resources, while recognizing solid institutional capacities for sustainable tourism development [66-68]. Many additional plans and projects further address the process of development of tourist destinations of Serbia (like regional plans, tourist destination master plans, and municipal development plans). Still, policymaking in Serbia's tourist sector is in a transitional phase generally due to the bureaucratic and autocratic system. Political decisions regarding sustainable tourism were mostly modeled on EU policies, based on various EU strategic frameworks and effective instruments (the Territorial Agenda of the European Union in 2007 [69], the European Union Strategy for Sustainable Development in 2006 [70], and the Agenda for Sustainable and Competitive European Tourism in 2007 [71], etc.). In the National Strategy of Sustainable Development [64], the fundamental concept of sustainable development is overgeneralized. Here, tourism is identified as an emerging sector with significant environmental impact but short of precise objectives or priority actions to make it more sustainable [72]. There have been frequent changes in legislation in all domains. However, these documents typically represent bare plans and political statements with little possibility for realization, commonly overusing and misunderstanding the concept of "sustainability". Even if the development of general and sectoral plans/strategies and programs has been intensified, there was a notable lack of inter-sectoral coordination and cooperation [72]. Often, national policies and strategic documents were elaborated by third parties, frequently engaging foreign experts unaware of pivotal national concerns and the current situation at destination levels. Thus, questions are raised about the realistic possibilities and the justifications for their practical implementation. This highlights a need for the creation of cooperative stakeholder networks in the policymaking process. As the tourism sector involves a vast 
number of stakeholders, this should lead to a dialog and negotiations to develop commonly desirable policies [73,74].

\section{Materials and Methods}

As the focus of the study was to understand policy enablers' perception of the sustainable development of tourist destinations in Serbia, a multi-stage methodology was chosen. The study applied the scholarship research approach [75] and combined theoretical and practical knowledge. This involved collecting data from using a qualitative (expert's judgment and content analysis) and quantitative method (interviews). The study followed the three core elements of the sustainable tourism conceptual model [76], including a modest set of indicators extracted from the European Tourism Indicator System (ETIS) [77] (Figure 1). In this line, the research queries hypothesize impacts by surveying policy-enablers' opinions. Structural equation modeling (SEM) was applied, which represents the relationships and critical paths between the factors.

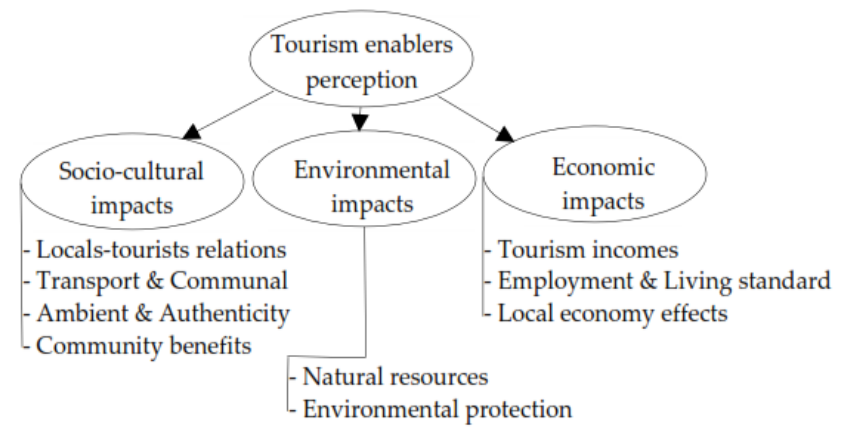

Figure 1. Conceptual sustainable tourism model and ETIS indicators. Source: adapted from [76,77].

A total of 219 half-structured deep interviews [78] were held in the local language with a conversation time ranging from 20-30 min. This included enumerators consisting of three researchers and six Ph.D. students performing interviews at different time stages, $3 \mathrm{~h}$ per each group (a senior and two students) daily (during the fair's working hours, 10-19 h). Each group had to mark the interviewees on the specially prepared list, which was transmitted to prevent overlapping. The interviews were conducted in the period February 22-25, 2018 at the International Belgrade Tourism Fair. The fair is considered one of the most important tourism events in Southeastern Europe and a gathering point for tourism providers at international and national levels. So far, various aspects of such fairs have been examined by scholars [79-83].

The interviews were undertaken by open-ended questions allowing the respondents to elaborate a freely structured discourse about the proposed topics, with minimal intervention to guide the process and perform quantification of responses. Before entering the interviewing process, a protocol was prepared. Piloting was performed to ensure the validity, clarity, and layout of the protocol. This also allowed the identification of possible omissions, irrelevant items, and determination of the time needed to finish the interviewing [84]. It was comprised of the following sections:

Section 1: Introduction. The research aim and the respondents' critical role in providing first-hand data were briefly explained.

Section 2: Perception (gathering quantitative data during the interview). A set of questions were asked to evaluate the policy with regard to socio-cultural, environmental and economic impacts (Figure 1). It comprised 12 selected ETIS sustainable indicators, as a sufficient base to assess the perception of policy enablers on revealing perceived sustainability level of tourist destinations [85]. The balanced number of driving forces, impact and response for all three basic sustainability levels was introduced. Neutrally phrased items were used to minimize ambiguity in interpretation $[61,62]$. 
Section 3: Enablers' policy and challenges (gathering qualitative data during the interview). The aim was to explore the challenges and the necessity of reform of tourism development in the destination.

Section 4: Interviewee data (Table 3).

Table 3. Interviewee data.

\begin{tabular}{|c|c|}
\hline Data & $\%\left(\sum=219\right)$ \\
\hline \multicolumn{2}{|l|}{ Gender } \\
\hline Male & 35.6 \\
\hline Female & 64.4 \\
\hline \multicolumn{2}{|l|}{ Age (years) } \\
\hline $18-35$ & 46.6 \\
\hline $36-60$ & 49.2 \\
\hline $60+$ & 4.2 \\
\hline \multicolumn{2}{|l|}{ Education } \\
\hline High school & 12.7 \\
\hline University & 87.3 \\
\hline \multicolumn{2}{|l|}{ Working position } \\
\hline Manager & 35.3 \\
\hline Employee & 64.7 \\
\hline \multicolumn{2}{|l|}{ Institution } \\
\hline Research unit & 4.2 \\
\hline Municipal institution & 66.4 \\
\hline Hotel \& Other & 15.1 \\
\hline Cultural center \& Other & 14.3 \\
\hline \multicolumn{2}{|l|}{ Policy level } \\
\hline Local & 79.0 \\
\hline Regional & 8.4 \\
\hline National & 10.9 \\
\hline International & 1.7 \\
\hline \multicolumn{2}{|l|}{ Type of organization } \\
\hline Public & 85.6 \\
\hline Private & 14.4 \\
\hline
\end{tabular}

During the interviews, full notes were carefully taken and respondents were invited to describe their perception of the current status of sustainability of tourism destination. By choosing from a five-point Likert Scale ( $1=$ strongly disagree to $5=$ strongly agree) quantitative data were collected on the degree at which each interviewee evaluates the three sustainability pillars. Collected data were transferred and processed in SPSS 24.0. The research applied exploratory factor analysis (EFA) on 12 ETIS indicators to identify coherent factors that represent the underlying dimension. A principal axis factor with an oblique rotation (Promax) was chosen to accommodate the possible correlation among factors. Structural equation modeling (critical path analysis model) was applied to the sample of 219 respondents as the fully appropriate sample size [86-88]. The model represents the relationships between the factors within the socio-cultural, environmental and economic impacts in Serbian tourist destinations.

After collecting the quantitative data, the interview protocol consisted of another consolidated set of direct questions related to tourism development challenges. Qualitative data were also collected, as interviewees were asked to briefly explain their insights about the broad spectrum of policy issues. The objective was to determine their first-hand perception of policy perspectives on reform challenges and the necessity of intervention in the current tourism development agenda at a local level. Respondents were also asked to suggest the inclusion of any missed but relevant aspect in terms of tourism policy reform. The sentences they used, repetition, and their vigor of expression, led to 
overall expert judgment. Subjective assessment enabled concise summarization and comprehensive compilation of the judicial sentences and empirical generalization of findings and conclusion.

Following the interviews, content analysis of the existing strategic tourism development documents was conducted. The aim was to reliably detect whether they properly address the sustainability issues typically identified by the respondents and systematically and objectively identify any possible inferences [89]. As sources were used national strategic planning documents (National Strategy on Sustainable Development [64] and the Strategy of Tourism Development [65]), regional development plans, tourist destinations' master plans, and municipal tourism development plans. They serve as a basis on which many decisions are made for tourist destinations. An assessment was carried out based on the extent to which existing strategic documents addressed issues of sustainability concern to policymakers, and how frequently they referred to the topics raised by the interviewees.

\section{Results}

Table 3 presents the full data of the interviewees' profiles. The target group consisted of representatives at all levels of tourism policy organizations: local $(79 \%)$, regional $(8.4 \%)$, national $(10.9 \%)$ and international $(1.7 \%)$. They were identified as the main policymakers for fostering an environment for sustainable development of tourist destinations. The respondents were managers $(35.3 \%)$ and employees $(64.7 \%)$ of public $(85.6 \%)$ and private organizations $(14.4 \%)$ retaining a comprehensive image of the tourism development process in Serbia. Specifically, they worked in research centers and universities $(4.2 \%)$, municipal institutions such as tourist organizations and offices $(66.4 \%)$, hotels and other establishments (15.1\%) and cultural and other associations $(14.3 \%)$. The respondents came from 79 municipalities, covering about $60 \%$ of all local tourist organizations in Serbia. There was strict domination of females $(64.4 \%)$ and highly educated respondents $(87.3 \%$ with university diploma). Almost half of the respondents (49.2\%) were between 36-60 years old, followed by those aged $18-45$ years $(46.6 \%)$, and there were only $4.2 \%$ older than 60 .

To explore the critical factors affecting the level of sustainability of tourist destinations in Serbia, respondents were invited to rate their level of agreement with sustainability indicators. Based on EFA, Table 4 presents the measurement variables for each impact factor in the form of a brief item providing sufficient internal consistency. A principal axis factoring was conducted with Promax rotation to determine the dimensionality of indicators. The total variance explained by three distinctive dimensions was $51.562 \%$, being moderate enough. This is satisfactory, particularly in tourism studies where information is often less precise [90]. The overall Cronbach's alpha value of the indicators was 0.83, which is above the suggested benchmark of 0.6 [91]. The Kaiser-Meyer-Olkin value of sample adequacy was 0.634 , being classified as a mediocre [90,92]. Bartlett's test is significant $(p<0.05)$ indicating the factor analysis is appropriate.

Socio-cultural sustainability indicators show a Cronbach's alpha value of 0.776 and explain $45.265 \%$ of the total variance. This impact represents two factors (Table 2, numbers F1 and F2) and both dimensions have high mean values. Each feature was set for further sub-dimensions. Thus, the first factor of the "Socio-cultural environment" has a Cronbach's alpha of 0.744 and a mean of 3.68 and consists of three items (social equity, authenticity of the destination, and cultural richness). The second socio-economic factor, "services", has a notably high Cronbach's alpha of 0.807 and a mean of 3.32, and consists of two items (transport services and communal services).

The second dimension, "environmental sustainability", and the third dimension, "economic sustainability", reflect with just one factor. The environmental sustainability produces a Cronbach's alpha of 0.882 and explains $55.463 \%$ of the total variance; the mean value is 3.16 , and it consists of two items (natural resources of the destination and local community involvement in environmental protection). Economic sustainability includes three items (economic viability, employment quality, and local prosperity). This explains $53.959 \%$ of the total variance, with a high Cronbach's alpha value of 0.832 , but the lowest mean value, 2.76 . The policy enablers dimension records a high mean value of 
3.79 , and might be considered a factor with a vital role in monitoring and managing of sustainability of tourist destinations.

Table 4. Tourism factors.

\begin{tabular}{|c|c|c|c|c|c|c|c|}
\hline No & Item & $\begin{array}{l}\text { Loading/Cro } \\
\text { Alpha }\end{array}$ & Mean & Std. dev & $\begin{array}{l}\text { Std. Error } \\
\text { Mean }\end{array}$ & $\mathbf{t}$ & $\begin{array}{c}\text { Sig. } \\
\text { (2-Tailed) }\end{array}$ \\
\hline & $\begin{array}{l}\text { SOCIO-CULTURAL } \\
\text { IMPACTS }\end{array}$ & 0.776 & & & & & \\
\hline$F 1$ & Socio-cultural environment & 0.744 & 3.68 & & & & \\
\hline 6 & Social equity & 0.730 & 3.59 & 0.964 & 0.065 & 7.301 & 0.000 \\
\hline 7 & $\begin{array}{l}\text { Authenticity of the } \\
\text { destination }\end{array}$ & 0.727 & 3.90 & 0.793 & 0.054 & 7.310 & 0.000 \\
\hline 10 & Cultural richness & 0.774 & 3.57 & 0.942 & 0.064 & 7.451 & 0.000 \\
\hline$F 2$ & Services & 0.807 & 3.32 & & & & \\
\hline 8 & Transport services & 0.807 & 3.33 & 0.973 & 0.066 & 5.558 & 0.000 \\
\hline 9 & Communal services & 0.807 & 3.31 & 0.916 & 0.062 & 7.610 & 0.000 \\
\hline$F 3$ & $\begin{array}{l}\text { ENVIRONMENTAL } \\
\text { IMPACTS }\end{array}$ & 0.882 & 3.16 & & & & \\
\hline 1 & Natural resources & 0.882 & 3.17 & 0.929 & 0.929 & 9.810 & 0.000 \\
\hline 2 & $\begin{array}{l}\text { Local community } \\
\text { involvement in } \\
\text { environmental protection }\end{array}$ & 0.882 & 3.15 & 1.027 & 1.027 & 10.052 & 0.000 \\
\hline$F 4$ & ECONOMIC IMPACTS & 0.832 & 2.76 & & & & \\
\hline 11 & Economic viability & 0.832 & 2.99 & 0.938 & 0.063 & 9.218 & 0.000 \\
\hline 12 & Employment quality & 0.819 & 2.71 & 1.006 & 0.068 & 9.376 & 0.000 \\
\hline \multirow[t]{2}{*}{13} & Local prosperity & 0.845 & 2.59 & 1.102 & 0.074 & 9.688 & 0.000 \\
\hline & POLICY ENABLERS & 0.900 & 3.79 & & & & \\
\hline 3 & $\begin{array}{l}\text { Monitoring sustainability } \\
\text { of tourist destination }\end{array}$ & 0.900 & 3.76 & 1.049 & 0.071 & 10.515 & 0.000 \\
\hline 4 & $\begin{array}{l}\text { Managing sustainability } \\
\text { of tourist destination }\end{array}$ & 0.900 & 3.82 & 0.977 & 0.066 & 10.097 & 0.000 \\
\hline
\end{tabular}

Extraction method: principal axis factoring. Rotation method: promax with Kaiser normalization.

Figure 2 presents the path analysis model indicating the relationships between the factors within the socio-cultural, environmental and economic impacts in Serbian tourist destinations. Some relations may be easily misinterpreted if respondents' answers are not properly addressed. Although it is logical to expect that transport and communal services may produce positive economic effects, here it is not the case. However, the respondents' distribution on the issue addressing the economic impacts explains the negative correlation. Namely, a substantial number of respondents expressed neutral perceptions on employment quality assessment, vis-à-vis the largest number of negative impressions concerning local prosperity issues. Similarly, one may explain the policy enablers' correlations. Questions concerning monitoring and managing of the sustainability levels at a destination also recorded mostly neutral statements. A negative assessment of $38.3 \%$ was evidenced in the case of evaluating the monitoring process, and $38.9 \%$ for assessing the management aspect of sustainability at destinations.

Table 5 presents the goodness-of-fit measures. Accordingly, the model fit was found very satisfactory, since all fit indices were above the cut-points [90]. The chi-square is significant, and, in comparison with the sample size, the ratio $\chi^{2} / \mathrm{df}$ has a value lower than 5 . Both CFI and IFI are above 0.9. RMSEA is slightly over 0.05 , and SRMR is well below 0.8 . 


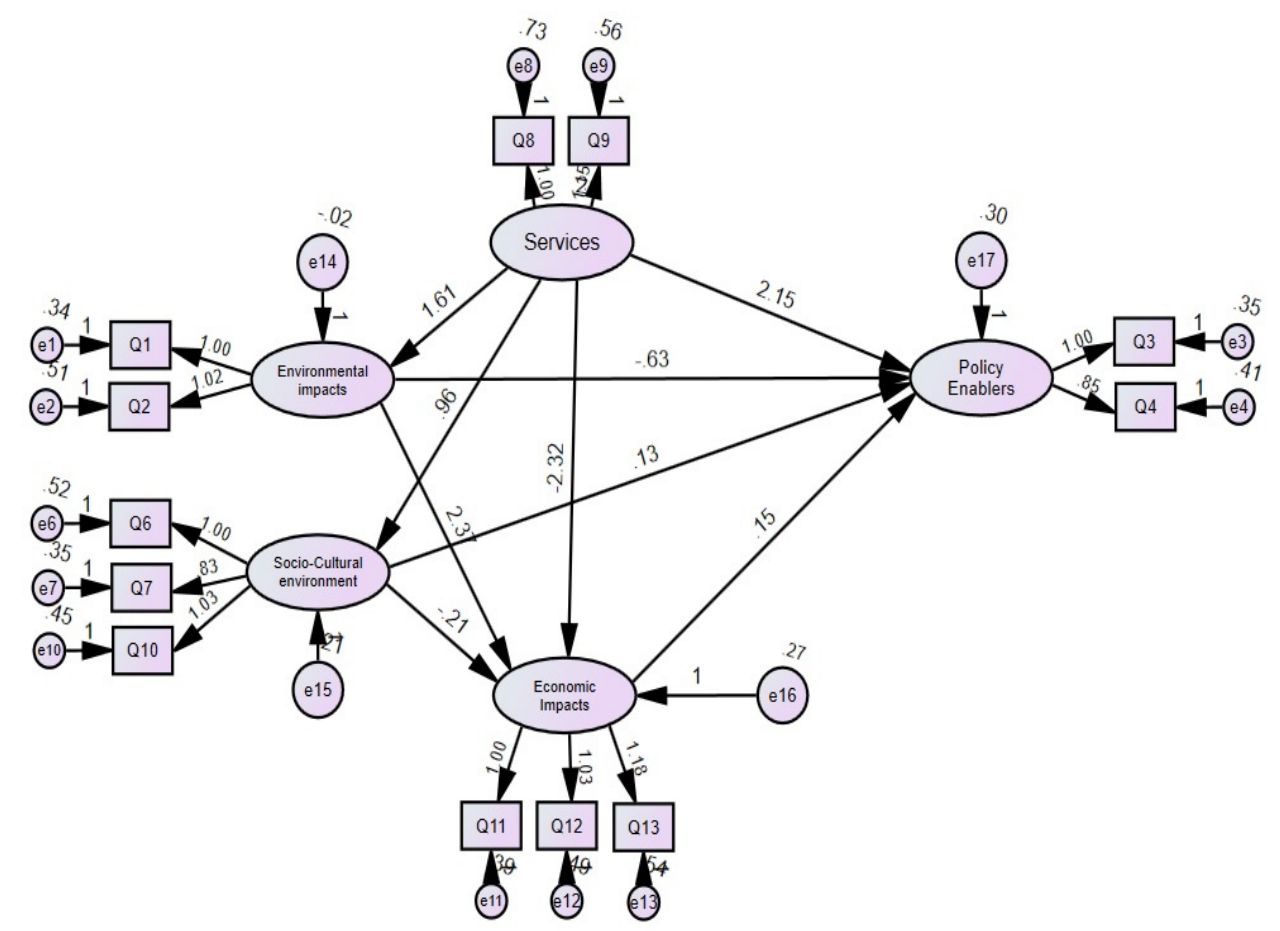

Figure 2. Path analysis model results.

Table 5. Goodness-of-fit measures.

\begin{tabular}{cccccccc}
\hline$\chi^{2}$ & $\mathbf{p}$ & $\mathbf{d f}$ & $\chi^{2} / \mathbf{d f}$ & CFI & IFI & RMSEA & SRMR \\
\hline 111.2 & 0.000 & 45 & 2.47 & 0.929 & 0.931 & 0.063 & 0.552 \\
\hline
\end{tabular}

\section{Findings and Discussion}

The research findings are elaborated in a two-fold manner. Firstly, the study assessed the policy perspective concerning the level of perceived sustainability of tourist destinations in Serbia. Secondly, upon the scholarly research approach, the study found many new insights for reforming current tourism development as well as some strategic challenges.

Assessing possible factors affecting the level of sustainability of tourist destinations in Serbia by policy enablers revealed that socio-cultural impacts are perceived as the most beneficial. Socio-cultural aspects like authenticity and uniqueness of destination act as the most relevant factors for sustainable development. As argued in [93], the cultural image often mediates environmental and economic perceptions at the destination level. Tourism policymakers outline that Serbian tourist destinations should focus on cultural values as an input of harmony, originality, and embrace of opposites, as argued by [94]. However, appropriate attention must be placed on the fact that cultural sensitiveness of tourist destinations calls for consistent monitoring. This also stands for social equity and cultural richness.

Surprisingly, the environmental factor was identified as having a medium impact for sustainability, unlike the notation in strategic documents, where the sustainable use of natural resources is strongly emphasized [65]. The ecological setting is found to be extremely fragile and sensitive [95], so the environmental sustainability (physical integrity, diversity, resource efficiency, environmental purity) was found hard to be perceived as the leading factor. Furthermore, the interviewed policymakers have recognized that environmental issues can be properly addressed only at higher development levels. Namely, tourism development in most destinations in Serbia is still small-scale and directly associated with socio-cultural factors and limited infrastructural capacities.

Although the dynamic economic environment makes it important to conduct monitoring of economic sustainability (employment, viability, local prosperity), policy perception on this issue has not researched the tipping point. Respondents indicate that policies are still primarily focused on issues 
related to infrastructure, product design, and marketing, and far less on supporting economic viability and facilitating local prosperity. This may jeopardize the wellbeing and livelihood of locals [96]. Therefore, it is essential to provide economic benefits to ensure locals' motivation to support tourism activities and preserve the destination's natural and cultural environment [24,51,97].

These categories are standardized and emerge as basic sustainable tourism principles, relevant to the destination's development. Consequently, these organizations are mostly concerned with planning for the present and future. However, such perceptions should be taken as personal and conceptual since what is perceived as sustainable practice differs between people and locations [98]. Since the parent theme was sustainable development, policy enablers highlighted the issue of re-shaping strategic documents to achieve access to sustainability. Even more, a concern that current tourism is focused solely on maintaining the number of tourists without taking care of responsible controlling has been raised. Tourism is commonly perceived to be on a maintainable level, although sometimes poor in quality, leading to a perception that support and coordination at all levels of policymaking are lacking. There is also a significant discrepancy in attitudes on prioritizing actions to improve the competitive position of Serbia in the international tourism market between the private and public sectors [23].

There is a general lack of cooperation between institutions and a reduced level of consolidation of different development goals, plans, and projects. Coordinated actions of defined stakeholders are missing, as they frequently exhibit a competitive rather than cooperative attitude, which is regarded the main obstacle in reaching sustainable development goals [22,99]. The role of local communities in the decision-making process is still extremely marginalized in Serbia, affecting perceived sustainability. Understanding the policy perspective allows current developing strategies to be assessed and re-shaped for their effectiveness and relevance to be developed. The qualitative analysis suggests changes in the policy context in a way to better embrace the key principles of sustainability [100]. The findings indicate a common belief that currently tourist destinations in Serbia are managed in a maintainable rather than in a sustainable manner. This means tourism is not operating at its optimum level, which flings a shadow of pessimism about the possibility to achieve sustainable grounds. As increasing tourist numbers in the destination remains an everlasting strategic goal, it simply confronts the sustainability principles. It was uncovered that, currently, policymakers are focused on sustaining some partial elements necessary for tourism development (such as ambient, authenticity, services, etc.), hence contributing merely to maintain the environmental quality [101,102]. This concept stands and works only in the short-term, unlike sustainability which represents a long-term, proactive and holistic approach [103]. This requires a change in perception, since sustainability no longer represents a strictly ecological concern (as in the case of strategic documents), but rather tackles a range of environmental, social, economic and other issues.

When comparing the results of content analysis of strategic tourism documents and personal perceptions of respondents, some overall convergences and divergences appeared. In terms of similarities, the same general perception that tourism in Serbia offers numerous benefits for tourist destinations and consequently should be positively acknowledged was uncovered. Similarities were also revealed in expressions of distress about the process of monitoring tourism product quality. Yet, rather than prevailing perceptions, several differences were noted, and a slight deviation occurred. Since tourism development documents typically reflect the broad concerns, the results suggest that they appeared to be less concerned with achieving sustainability than the interviewed policymakers. Namely, the documents contain directions focused on gaining positive impacts, omitting the essential elements of sustainability. Hence, they pose many so-called 'strategic areas of intervention', which were determined as primary concerns for enabling tourism growth. As such, current strategic documents lack the substantial element of the main definition of sustainability—enhancing local opportunities for the future [85]. This represents the main concern of policymakers when interviewed in person.

To summarize, the content analysis illustrated that current development plans and policies did not reflect real policy enablers' perceptions, but rather reflect those for just supporting maintainable tourism. The integral development component is missing as a key factor in reaching sustainability. 
Ultimately, such a maintainable pattern may result in almost immediate positive tourism effects. However, sustainability will not exist until it is managed in such a way that differs from general policy directions [104]. This means that reforming current policy orientation is inevitable, which will lead to the inclusion of a broader perception as a crucial advantage in understanding and practicing sustainability. Indeed, until perceptions are thoroughly incorporated into strategic documents, management and monitoring of resources in tourist destinations in Serbia may continue to be perceived as unsustainable. This means tourism will most likely continue its development process without reaching general sustainability goals. As such, it may inevitably lead to exploitation and eventually deterioration of destinations and local resources.

\section{Conclusions}

This study examined the perceptions of policy enablers and explored the main challenges for tourist destinations in terms of sustainability. It has found that socio-cultural impacts are perceived as important for achieving sustainability when developing tourist destinations in Serbia. It also suggested a model that presents the relationship between factors within socio-cultural, environmental and economic impacts. It assists in monitoring and managing tourism activities and their impacts. As the model is developed in the case of Serbian tourist destinations, every generalization of the proposed model must consider that issues of sustainable development may vary from one place to another. There is a need to formulate place-specific policies with the ability to recognize the particular context of sustainability at the local level $[56,105]$. Implementing this model provides a possibility for managers and policy enablers to detect sustainability problems in a given tourist destination. The model also assists comprehension of how to initiate and carry out informed decisions with the aim of ensuring the destination's sustainability [37]. In the absence of such a framework, it would be challenging to identify issues and areas of intervention, and eventually duplicate efforts and waste resources. This enables a much smoother way for decision-makers to perceive the interconnection between the factors of influence and prioritize the action areas. As such, policymakers can be proactive in identifying problems and bridge the gap in due time.

The research confirmed that tourist destinations in Serbia need to re-shape their development plans and policies. As noted by [50], the accent should be on guaranteeing the social sustainability of the destination, unlike current policies that are missing that element. Thus, although it is declared for strategic documents that they foster tourism development by contributing to its sustainability, it was confirmed that they do not provide a broader picture. Conversely, such plans and documents manage the status quo to keep up with short-term impacts, staying focused predominantly on the quality of the product. Such an approach is increasing the risk of inappropriate monitoring and management at the destination level.

Several limitations were noted for this research, which may be addressed in some future work. Initially, data collection was performed during a tourism fair at an extremely busy time, so the perception of respondents might be a bit neglected. Second, the interview involved a rather limited set of sustainable indicators, opening the possibility for further expansion. Third, the sample was taken based on convenience sampling, so probability sampling techniques may be further introduced. Fourth, the study explored the case of Serbia and provides the most effective 'micro' solution to what remains essentially a 'macro' problem. Ultimately, the research departed from the conventional triple bottom line of sustainability, so some additional dimensions of sustainability might be included. Adding the aspect of institutional sustainability may broaden understandings on local planning policy, local-oriented control policy, political participation, political support, etc. The total variance explained may also be improved beyond the current moderate level of $51.562 \%$. Nevertheless, the study presents a broad context of tourist destinations' sustainability and enables a better understanding of the current policy level attitude.

Author Contributions: Conceptualization, B.P. and A.T.; methodology, B.P.; software, C.A.; validation, C.A. and B.P.; formal analysis, B.P. and C.A.; investigation, A.T.; resources, A.T.; data curation, A.T.; writing-original draft 
preparation, B.P.; writing-review and editing, B.P. and A.T.; visualization, B.P. and C.A. All authors have read and agreed to the published version of the manuscript.

Funding: This research received no external funding.

Conflicts of Interest: The authors declare no conflict of interest.

\section{References}

1. UNEP. World Charter for Nature; UNEP: Nairobi, Kenya, 1982.

2. UNCED-United Nations Conference on Environment and Development. Agenda 21. 1992. Available online: www.ciesin.org/TG/P1/TREATY/unced.html (accessed on 25 March 2020).

3. UN. World Summit on Sustainable Development Report. 2002. Available online: https://www.un.org/ga/ search/view_doc.asp?symbol=A/CONF.199/20/Corr.1\&Lang=E (accessed on 25 March 2020).

4. UNCED-United Nations Conference of Sustainable Development, Rio +20. 2012. Available online: https://sustainabledevelopment.un.org/rio20/futurewewant (accessed on 25 March 2020).

5. UNSD—SGD Indicators Global Database. 2018. Available online: https://unstats.un.org/sdgs/indicators/ database/ (accessed on 25 March 2020).

6. Hak, T.; Januškova, S.; Moldan, B. Sustainable Development Goals: A need for relevant indicators. Ecol. Indic. 2016, 60, 565-573. [CrossRef]

7. Cerin, P. Bringing economic opportunity into line with environmental theorem and the Porter and van der Linde hypothesis. Ecol. Econ. 2006, 56, 209-225. [CrossRef]

8. Zhai, T.T.; Chang, Y.C. Standing of environmental public-interest litigants in China: Evolution, obstacles and solutions. J. Environ. Law 2019, 30, 369-397. [CrossRef]

9. Mensah, J.; Ricart Casadevall, S. Sustainable development: Meaning, history, principles, pillars, and implications for human action: Literature review. Cogent. Soc. Sci. 2019, 5, 1653531. [CrossRef]

10. UN. Transforming Our World: The 2030 Agenda for Sustainable Development, A/RES/70/1. 2015. Available online: https://sustainabledevelopment.un.org/content/documents/21252030\%20Agenda\%20for\% 20Sustainable\%20Development\%20web.pdf (accessed on 25 March 2020).

11. Gupta, J.; Vegelin, C. Sustainable development goals and inclusive development. Int. Environ. Agreem. Politics Law Econ. 2016, 16, 433-448. [CrossRef]

12. Harrill, R. Residents' attitudes toward tourism development: A literature review with implications for tourism planning. J. Plan. Lit. 2004, 18, 251-266. [CrossRef]

13. Sharpley, R. Host perceptions of tourism: A review of the research. Tour. Manag. 2014, 42, 37-49. [CrossRef]

14. Popescu, G.H.; Sima, V.; Nica, E.; Gheorghe, I.G. Measuring sustainable competitiveness in contemporary economies-Insights from European economy. Sustainability 2017, 9, 1230. [CrossRef]

15. Ko, T. Development of a tourism sustainability assessment procedure: A conceptual approach. Tour. Manag. 2005, 26, 431-445. [CrossRef]

16. Viljoen, F. Sustainability Indicators for Monitoring Tourism Route Development in Africa. Ph.D. Thesis, University of Stellenbosch, Stellenbosch, South Africa, 2007.

17. Choi, H.; Sirakaya, E. Measuring residents' attitude toward sustainable tourism: Development of sustainable tourism attitude scale. J. Travel Res. 2005, 43, 380-394. [CrossRef]

18. Cottrell, S.; Vaske, J. A framework for monitoring and modeling sustainable tourism. eRTR 2006, 4, 4 .

19. Shen, F.; Cottrell, S. A sustainable tourism framework for monitoring residents' satisfaction with agritourism in Chongdugou Village, China. Int. J. Tour. Policy 2008, 1, 4. [CrossRef]

20. Timur, S.; Getz, D. Sustainable tourism development: How do destination stakeholders perceive sustainable urban tourism? J. Sustain. Dev. 2009, 17, 220-232. [CrossRef]

21. Ramdas, M.; Mohamed, B. Visitor perceptions on the impacts of tourism activities, development and infrastructure on the environment of Perhentian Islands. SHS Web Conf. 2014, 12, 10. [CrossRef]

22. Dwyer, L.; Dragićević, V.; Armenski, T.; Mihalič, T.; Knežević Cvelbar, L. Achieving destination competitiveness: An importance-Performance analysis of Serbia. Curr. Issues Tour. 2016, 19, 1309-1336. [CrossRef]

23. Armenski, T.; Dwyer, L.; Pavluković, V. Destination competitiveness: Public and private sector tourism management in Serbia. J. Travel Res. 2018, 57, 384-398. [CrossRef] 
24. WCED—World Commission on Environment and Development. Our Common Future; Oxford University Press: Melbourne, Australia, 1987.

25. Balaban, M.; Župljanin, S.; Nešović, D. Regional sustainability of local and rural development. Econ. Agric. 2019, 66, 1173-1186. [CrossRef]

26. Andrei, D.R.; Gogonea, R.M.; Zaharia, M.; Andrei, J.V. Is Romanian rural tourism sustainable? Revealing particularities. Sustainability 2014, 6, 8876. [CrossRef]

27. Liu, Z. Sustainable tourism development: A critique. J. Sustain. Tour. 2003, 11, 459-475. [CrossRef]

28. Butler, R.W. Sustainable tourism: A state-of-the art review. Tour. Geogr. 1999, 1, 7-25. [CrossRef]

29. Middleton, V.T.C.; Hawkins, R. Sustainable Tourism: A Marketing Perspective; Butterworth-Heinemann: Oxford, UK, 1998.

30. Garrod, B.; Fyall, A. Beyond the rhetoric of sustainable tourism. Tour. Manag. 1998, 19, 199-212. [CrossRef]

31. Fossati, A.; Panella, G. Tourism and sustainable development: A theoretical framework. In Tourism and Sustainable Economic Development; Fossati, A., Panella, G., Eds.; Kluwer Academic: Dordrecht, The Netherlands, 2000; pp. 3-23.

32. Pearce, D.; Barbier, E.; Markandya, A. Sustainable Development: Economics and Environment in the Third World; Edward Elgar: London, UK, 1990.

33. Bramwell, B. Selecting policy instruments for sustainable tourism. In Global Tourism; Theobald, W.F., Ed.; Butterworth Heinemann: Oxford, UK, 1998; pp. 361-379.

34. Wahab, S.; Pigram, J.J. Tourism and sustainability: Policy considerations. In Tourism, Development and Growth. The Challenge of Sustainability; Wahab, S., Pigram, J.J., Eds.; Routledge: London, UK, 1998; pp. 277-290.

35. Mahdav, D.; Parishan, M.; Hasar, A. Practical model for measuring progress towards sustainable rural tourism development (SRTD) in rural area of Iran. IRJABS 2013, 5, 1073-1082.

36. Huang, W. Good Practice in Sustainable Tourism: Developing a Measurement System by Providing a Model Assessment Procedure. Master's Thesis, IIIEE, Lund, Sweden, 2011.

37. Cernat, L.; Gourdon, J. Paths to success: Benchmarking cross-Country sustainable tourism. Tour. Manag. 2012, 33, 1044-1056. [CrossRef]

38. Alzboun, N. Assessment of the effect of sustainability practices on financial Leakage in the hotel industry in Jordan. Ph.D. Thesis, Clemson University, Clemson, SC, USA, 2014.

39. Byrd, E.T. Stakeholders in sustainable tourism development and their roles: Applying stakeholder theory to sustainable tourism development. Tour. Rev. 2007, 62, 6-13. [CrossRef]

40. Byrd, E.T.; Bosley, H.E.; Dronberger, M.G. Comparisons of stakeholder perceptions of tourism impacts in rural eastern North Carolina. Tour. Manag. 2009, 30, 693-703. [CrossRef]

41. Garrod, B.; Fyall, A.; Leask, A.; Reid, E. Engaging residents as stakeholders of the visitor attraction. Tour. Manag. 2012, 33, 1159-1173. [CrossRef]

42. Nicholas, L.; Thapa, B.; Ko, Y. 2009. Residents' perspectives of a world heritage site-the Pitons Management Area, St. Lucia. Ann. Tour. Res. 2009, 36, 390-412. [CrossRef]

43. Šegota, T.; Mihalič, T.; Kuščer, K. The impact of residents' informedness and involvement on their perceptions of tourism impacts: The case of Bled. JDMM 2017, 6, 196-206. [CrossRef]

44. Coldwell, W. The Guardian. First Venice and Barcelona: Now Anti-Tourism Marches Spread across Europe. 10 August 2017. Available online: https://www.theguardian.com/travel/2017/aug/10/anti-tourism-marchesspread-across-europe-venice-barcelona (accessed on 21 September 2019).

45. Coldwell, W. The Guardian. Wish You Weren't Here: How the Tourist Boom-and Selfies-Are Threatening Britain's Beauty Spots. 16 August 2018. Available online: https://www.theguardian.com/travel/2018/aug/16/ wish-you-werent-here-how-the-tourist-boom-and-selfies-are-thretening-britains-beauty-spots (accessed on 21 September 2019).

46. Dioko, A.N. The problem of rapid tourism growth: An overview of the strategic question. Worldw. Hosp. Tour. Themes 2017, 9, 252-259. [CrossRef]

47. Hughes, N. 'Tourists go home': Anti-Tourism industry protest in Barcelona. Soc. Mov. Stud. 2018, 17, 471-477. [CrossRef]

48. Kuščer, K.; Mihalič, T. Resident's attitudes towards overtourism from perspective of tourism impacts and cooperation-The case of Ljubljana. Sustainability 2019, 11, 1823. [CrossRef] 
49. Martín Martín, J.M.; Guaita Martínez, J.M.; Salinas Fernández, J.A. An analysis of the factors behind the citizen's attitude of rejection towards tourism in a context of overtourism and economic dependence on this activity. Sustainability 2018, 10, 2851. [CrossRef]

50. Seraphin, H.; Sheeran, P.; Pilato, M. Over-Tourism and the fall of Venice as a destination. JDMM 2018, 9, 374-376. [CrossRef]

51. Stylidis, D.; Biran, A.; Sit, J.; Szivas, E.M. Residents' support for tourism development: The role of residents' place image and perceived tourism impacts. Tour. Manag. 2014, 45, 260-274. [CrossRef]

52. Terzić, A. Cultural Tourism Issues and the Role of Local Communities. In Danube: Future Interdisciplinary School Proceedings 2017: Cultural and Social Implications of Global Change on the Danube River Basin; Edition Donau-Universität Krems: Krems, Germany, 2019.

53. VALICON. Residents' Attitudes towards Tourism in Ljubljana; Report, Based on Research TLJ104; Slovenian Tourist Board: Ljubljana, Slovenia, 2017.

54. Boley, B.B.; McGehee, N.G.; Perdue, R.R.; Long, P. Empowerment and resident attitudes toward tourism: Strengthening the theoretical foundation through a Weberian lens. Ann. Tour. Res. 2014, 49, 33-50. [CrossRef]

55. Latkova, P.; Vogt, C.A. Resident attitudes towards existing and future tourism development in rural communities. J. Travel Res. 2012, 51, 50-67. [CrossRef]

56. Nunkoo, R.; Ramkissoon, H. Developing a community support model for tourism. Ann. Tour. Res. 2011, 38, 964-988. [CrossRef]

57. Nunkoo, R.; Ramkissoon, H. Power, trust, social exchange and community support. Ann. Tour. Res. 2012, 39, 997-1023. [CrossRef]

58. Nunkoo, R.; Ramkissoon, H.; Gursoy, D. Public trust in tourism institutions. Ann. Tour. Res. 2012, 39, 1538-1564. [CrossRef]

59. Ap, J.; Crompton, J. Developing and testing a tourism impact scale. J. Travel Res. 1998, 37, 120-130. [CrossRef]

60. Miller, G. The development of indicators for sustainable tourism: Results of a Delphi survey of tourism researchers. Tour. Manag. 2001, 22, 351-362. [CrossRef]

61. Mbaiwa, J.; Bernard, F.; Orford, C. Limits of acceptable change for tourism in the Okavango Delta. Botsw. Notes Rec. 2008, 38, 92-112.

62. Choi, H.; Murray, I. Resident attitudes toward sustainable community tourism. J. Sustain. Tour. 2010, 18, 575-594. [CrossRef]

63. Statistical Office of the Republic of Serbia. Statistical Data for 2019. Available online: www.stat.gov.rs (accessed on 25 February 2020).

64. Official Gazette of the Republic of Serbia, 57/2008; National Strategy of Sustainable Development: Belgrade, Serbia, 2008.

65. Official Gazette of the Republic of Serbia, 98/2016. Strategy of Tourism Development 2016-2025; Belgrade, Serbia, 2016.

66. Orlović-Lovren, V.; Crnčević, T.; Milijić, S. Tourism development in Serbia: On the way to sustainability and European integration. Spatium 2013, 47-53. [CrossRef]

67. Končar, J.; Grubor, A.; Marić, R. Improving the placement of food products of organic origin on the AP Vojvodina market. Strateg. Manag. 2019, 24, 24-32. [CrossRef]

68. Dencic-Mihajlov, K. Does sustainability matter in mergers and acquisitions? The case of the Serbian food industry. Econ. Agric. 2020, 67, 25-36. [CrossRef]

69. Agenda, T. Territorial agenda of the European Union: Towards a more competitive and sustainable Europe of diverse regions-agreed at the occasion of the Informal Ministerial Meeting on Urban Development and Territorial Cohesion on 24/25 May 2007. Available online: http://www.bmvbs.de/Anlage/original_ 1005295/Territorial-Agenda-of-the-European-Union-Agreed-on-25-May-2007-accessible.pdf (accessed on 21 September 2019).

70. European Commission. A European Union Strategy for Sustainable Development. 2006. Available online: http://ec.europa.eu/sustainable (accessed on 1 March 2020).

71. European Commission. Agenda for a Sustainable and Competitive European Tourism, COM 621. 2007. Available online: http://ec.europa.eu/enterprise/sectors/tourism/documents (accessed on 1 March 2020).

72. Maksin, M.; Milijić, S. Strategic planning for sustainable spatial, landscape and tourism development in Serbia. Spatium 2010, 23, 30-37. [CrossRef] 
73. Bramwell, B.; Lane, B. Tourism Collaboration and Partnerships: Politics, Practice and Sustainability; Channel View Publications: Clevedon, UK, 2000.

74. Terzić, A. Pristup umrežavanja aktera kao neophodan faktor razvoja kulturnog turizma u Srbiji. Kultura 2016, 150, 254-270. [CrossRef]

75. Van de Ven, A.H. Engaged Scholarship: A Guide for Organizational and Social Research; Oxford University Press: Oxford, UK, 2007.

76. Mihalič, T. Sustainable-Responsible tourism discourse-Towards 'responsustable' tourism. J. Clean. Prod. 2016, 111, 461-470. [CrossRef]

77. European Commission. The European Tourism Indicator System: ETIS Toolkit for Sustainable Destination Management; Publications Office of the EU: Luxemburg, 2016.

78. Trainor, A.A. Interview research. In Reviewing Qualitative Research in the Social Sciences; Routledge: London, UK, 2013; pp. 137-150.

79. Herbig, P.; O’Hara, B.; Palumbo, F.A. Trade shows: Who, what, why. Mark. Intell. Plan. 1998, 16, $425-435$. [CrossRef]

80. Gopalakrishna, S.; Lilen, G.L.; Willams, J.D.; Sequeira, I.K. Do trade shows pay off? J. Mark. 1995, 59, 75-83. [CrossRef]

81. Kijewski, V.; Yoon, E.; Young, G. How exhibitors select trade shows. Ind. Mark. Manag. 1993, 22, $287-298$. [CrossRef]

82. Berne, C.; Garcia-Uceda, M. Targeting efficiencies among trade show nonattendees. J. Target. Meas. Anal. Market. 2007, 15, 146-157. [CrossRef]

83. Li, L.Y. Marketing resources and performance of exhibitor firms in trade shows: A contingent resource perspective. Ind. Mark. Manag. 2007, 36, 360-370.

84. Cohen, L.; Manion, L.; Morrison, K. Research Methods in Education, 6th ed.; Taylor and Francis Group: London, UK, 2007.

85. WTO-World Tourism Organization. Indicators of Sustainable Development for Tourism Destinations: A Guidebook; WTO: Madrid, Spain, 2004.

86. Kline, P. The Handbook of Psychological Testing, 2nd ed.; Routledge: London, UK, 1999.

87. Byrne, B. Structural Equation Modeling with AMOS: Basic Concepts, Applications, and Programming, 2nd ed.; Taylor \& Francis Group: New York, NY, USA, 2010.

88. Iacobucci, D. Structural equations modeling: Fit indices, sample size, and advanced Topics. J. Consum. Psychol. 2010, 20, 90-98. [CrossRef]

89. Stone, P.J.; Dunphy, D.C.; Smith, M.S.; Ogilvie, D.M. The General Inquirer: A Computer Approach to Content Analysis; MIT Press: London, UK, 1966.

90. Hair, J.; Anderson, R.; Tatham, R.; Black, W. Multivariate Data Analysis; Prentice Hall: New Jersey, USA, 2005.

91. Nunnally, J.; Bernstein, I.H. Psychometric Theory, 3rd ed.; McGraw-Hill: New York, NY, USA, 1994.

92. Field, A. Discovering Statistics Using SPSS, 3rd ed.; SAGE Publications Inc.: London, UK, 2009.

93. Lee, S.W.; Xue, K. A model of destination loyalty: Integrating destination image and sustainable tourism. Asia Pac. J. Tour. Res. 2020, 25, 393-408. [CrossRef]

94. Weaver, D.B.; Tang, C.; Zhao, Y. Facilitating sustainable tourism by endogenization: China as exemplar. Ann. Tour. Res. 2020, 81, 102890. [CrossRef]

95. Schianetz, K.; Kavanagh, L.; Lockington, D. Concepts and tools for comprehensive sustainability assessments for tourism destinations: A comparative review. J. Sustain. Tour. 2007, 15, 369-389. [CrossRef]

96. Friedmann, J. Empowerment: The Politics of Alternative Development; Basil Blackwell: New York, NY, USA, 1992.

97. Perdue, R.R.; Long, P.T.; Allen, L. Resident support for tourism development. Ann. Tour. Res. 1990, 17, 586-599. [CrossRef]

98. Kearsley, G.W.; Kliskey, A.D.; Highma, J.E.S.; Higham, E.C. Perception of wilderness in the South Island of New Zealand: A multiple images approach. In Proceedings of the 8th Australian Tourism and Hospitality Research Conference, Gold Coast, Australia, 11-14 February 1998.

99. Dudwick, N.; Kuehnast, K.; Jones, V.N.; Woolcock, M. Analyzing Social Capital in Context. A Guide to Using Qualitative Methods and Data; Working Paper No. 38917; World Bank Institute: Washington, DC, USA, 2006; pp. 1-46. 
100. Coccossis, H. Sustainable tourism and carrying capacity: A new context. In The Challenge of Tourism Carrying Capacity Assessment; Routledge: London, UK, 2017; pp. 19-30.

101. Bell, S.; Morse, S. Sustainability Indicators: Measuring the Immeasurable? 2nd ed.; Earthscan Publication for Sustainable Future: London, UK, 2008.

102. Weaver, D.; Lawton, L. Sustainable Tourism: A Critical Analysis; Cooperative Research Centre for Sustainable Tourism: Gold Coast, Queensland, Australia, 1999.

103. Vehbi, B. A Model for Assessing the Level of Tourism Impacts and Sustainability of Coastal Cities. In Strategies for Tourism Industry-Micro and Macro Perspectives; Kasimoglu, M., Ed.; InTech: Rijeka, Croatia, 2012; pp. 99-114.

104. Hardy, A.L.; Beeton, R.J. Sustainable tourism or maintainable tourism: Managing resources for more than average outcomes. J. Sustain. Tour. 2001, 9, 168-192. [CrossRef]

105. Teye, V.; Sönmez, S.F.; Sirakaya, E. Residents' attitudes toward tourism development. Ann. Tour. Res. 2002, 29, 668-688. [CrossRef]

(C) 2020 by the authors. Licensee MDPI, Basel, Switzerland. This article is an open access article distributed under the terms and conditions of the Creative Commons Attribution (CC BY) license (http://creativecommons.org/licenses/by/4.0/). 